\title{
SURFACE MODIFICATION OF CHEMICAL VAPOR DEPOSITION (CVD) DIAMOND ISILICON FILM(111) BY IMPLANTATION WITH FE + B IONS AND THEIR MAGNETIC PROPERTIES
}

\section{MODIFIKASI PERMUKAAN FILM CVD INTAN/SILIKON(111) DENGAN IMPLANTASI ION FE + B DAN SIFAT MAGNETIK BAHAN}

\author{
Setyo Purwanto1, A. Dimyati' ${ }^{1}$, R. Iskandar ${ }^{2}$, Wisnu A.A ${ }^{1}$, Tjipto $\mathbf{S}^{3}$ \\ ${ }^{1}$ Center for Advanced Material Science and Technology-BATAN, Kawasan Puspiptek Sepong, 15314 \\ ${ }^{2}$ Facility for Electron Microscopy, RWTH Aachen, Germany \\ ${ }^{3}$ Center for Accelerator Science and Technology-BATAN, Indonesia \\ e-mail: setyo_p@batan.go.id or purwantosetyo@yahoo.com
}

Received 7 March 2017, received in revised form 29 May 2017, accepted 1 August 2017

\begin{abstract}
SURFACE MODIFICATION OF CHEMICAL VAPOR DEPOSITION (CVD) DIAMOND/SI(111) FILM BY IMPLANTATION WITH Fe+B IONS AND THEIR MAGNETIC PROPERTIES. Surface modification of CVD manufactured diamond films on Si(111) substrate has been performed by means of $\mathrm{Fe}+B$ ion implantation followed by Argon ion gas sputtering with acceleration energy $20 \mathrm{keV}$ and ion dose $1 \times 10^{15}$ and $1 \times 10^{16}$ ions $\mathrm{cm}^{-2}$. Scanning Transmission Electron Microscope (STEM) imaging shows the formation of amorphous carbon layer on top of the diamond film with thickness ca. $100 \mathrm{~nm}$ on the implanted sample and ca. $20 \mathrm{~nm}$ on the sample without implantion. The morphology and magnetic property of the films surface were characterized by Atomic and Magnetic Force Microscopy (AFM/MFM). The Electron Energy Loss Spectroscopy EELS analysis has revealed amount of Boron atoms distributed homogenously inside the carbon amorphous layer on both samples which is in close agreement to the result of Raman Spectroscopy showing the changes of the Raman spectrum due to implantation. The magnetic properties of the samples after Fe+B ion implantion were additionally investigated by means of Vibrating Sample Magnetometer (VSM). By increasing ion doses at constant energy $20 \mathrm{keV}$, the magnetoresistance property decreased from $+45 \%$ on the sample implanted with dose $1 \times 10^{15}$ to $+8 \%$ on the sample implanted with dose $1 \times 10^{16}$ ions $\mathrm{cm}^{-2}$.
\end{abstract}

Keywords: CVD Diamond film, ion implantation, magnetoresistance, nanostructure

\section{ABSTRAK}

\begin{abstract}
MODIFIKASI PERMUKAAN FILM CVD INTAN/Si(111) DENGAN IMPLANTASI ION Fe + B DAN SIFAT MAGNETIK BAHAN. Modifikasi permukaan film CVD (Chemical Vapor Deposition) dengan substrat Si(111) telah dilakukan dengan teknik implantasi ion $\mathrm{Fe}+B$ yang diikuti dengan proses sputering ion gas Argon pada akselerasi energi $20 \mathrm{keV}$ pada dosis ion $1 \times 10^{15}$ and $1 \times 10^{16} \mathrm{~cm}^{-2}$. Citra STEM (Scanning Transmission Electron Microscope) memperlihatkan adanya pembentukan lapisan Karbon amorf pada lapisan paling atas dari film Intan dengan ketebalan kurang lebih $100 \mathrm{~nm}$ untuk cuplikan yang terimplantasi dan tebal $20 \mathrm{~nm}$ untuk cuplikan yang tidak terimplantasi. Morfologi dan sifat magnetik permukaan film dikarakterisasi dengan AFM/MFM (Atomic dan Magnetic Force Microscopy). Hasil analisis dengan teknik EELS (Electron Energy Loss Spectroscopy) memperlihatkan keberadaan atom Boron yang tersebar secara merata di dalam lapisan amorf Karbon dan hal ini bersesuaian dengan citra spektroskopi Raman untuk kedua cuplikan. Sifat magnetik film dapat teramati dengan VSM (Vibrating Sample Magnetometer), sedangkan sifat magnetoresistance bahan diukur dengan teknik Four point probe. Diperoleh hasil bahwa seiring dengan meningkatnya dosis ion pada energi tetap $20 \mathrm{keV}$, nisbah magnetoresistance berkurang dari positip 45\% pada sampel terimplantasi dengan dosis $1 \times 10^{15}$ menjadi $8 \%$ pada sampel terimplantasi dengan dosis $1 \times 10^{16}$ ion $\mathrm{cm}^{-2}$.
\end{abstract}

Kata kunci: Film CVD intan, implantasi ion, magnetoresistance, struktur nano 


\section{INTRODUCTION}

$D^{\text {ingsing }}$ amonds naturally are strong diamagnetic. However, their ferromagnetic property can be enhanched either by ion implantation which is directly correlated to the defects formation or by addition of atom size impurities. Talapatra et al. [1] found ferromagnetism (FM) in nanosize diamond crystalls as a result of nitrogen and carbon ion implantion. This finding opens the possibility of using diamond for many electronic applications such as nano size magnetometry [2]. SRIM [3] has revealed that the defect density threshold by boron ion, beyond which graphitization occurs during annealing is as high as $10^{22}$ vacancies $/ \mathrm{cm}^{3}$. Tavares et al.[4] were develop p-type diamond single crystal layer on (111) oriented diamond substrates grown by Microwave Plasma-enhanced Vapor Deposition (MPCVD). Hohne et al. [5] studied the boron, fluorine or iron implantation on the diamond film to produce structures with different degrees of lattice damage and their magnetic properties. On the other hand, Y.J. Fei et al. [6] obtained longitudinal resistance change rate is up to $+20 \%$ at 20 Tesla and temperature $300 \mathrm{~K}$ at post implanted boron with dose $3 \times 10^{19}$ ions $\mathrm{cm}^{-2}$. Unfortunately, there are no information about any research works which investigate the role of implantation with low doses ions $\mathrm{Fe}+\mathrm{B}$ on the surface of CVD diamond/Si(111).

In this present work, the ion beam irradiation was applied with the aim to modify the structure of CVD manufactured diamond film on Silicon(111) substrate in order to increase the magnetic property. At first step $\mathrm{Fe}+\mathrm{B}$ ions of various doses but at constant acceleration energy $20 \mathrm{keV}$ have been deposited on the diamond film surface followed by Argon ion sputtering at $70 \mathrm{keV}$ and dose $10^{16}$ ion $\mathrm{cm}^{-2}$. The direction oriented $\mathrm{Si}(111)$ substrate was used to keep the diamond structure of the film even after ion implantation. We postulate that ion implantation of certain atoms such as Fe or B, or their combination and subsequent ion sputtering by Argon could bring the positive effect to the magnetic properties of diamond film which give rise to the magnetoresistance property at low magnetic field.

\section{METHODOLOGY}

CVD diamond film of $1300 \mathrm{~nm}$ thickness on Silicon wafer (111) used in this work was manufactured and supplied by Applied Diamond Inc. USA. Two samples of such diamond films were implanted by Fe+B ion at energy $20 \mathrm{kev}$ with ion doses $1 \times 10^{15}$ (thereafter called B-E1D1) and $1 \times 10^{16}$ ion $\mathrm{cm}^{-2}$ (called as B-E1D2) followed by Argon ion sputtering at $70 \mathrm{kev}$ and dose $10^{16} \mathrm{ions} \mathrm{cm}^{-2}$. Phase identification of the film was performed using Raman Spectroscopy. The magnetization measurements were carried out using an Oxford VSM. The samples were cut from the bulk with area of about $4 \mathrm{~mm}^{2}$. The characteristic hysteresis loop was measured between +1 and -1 Tesla at room temperature. The magnetoresistance measurements were carried out by Four Point Probe technique at magnetic field up to 0.8 Tesla at room temperature. All the measurements were taken at PSTBM-BATAN. Implantation process was performed by lon Implanter at PSTA-BATAN in Jogjakarta. The microstructure of the film was characterized by TEM FEI Tecnai G2 with acceleration energy 200 kev equipped with EELS and Energy Filter at the Central Facility for Electron Microscopy at RWTH Aachen University of Technology, Germany. All the samples for TEM investigation were prepared in the Focus lon Beam workstation (FIB) FEI Strata 205. The detail description about the FIB preparation technique has been reported in [7]. Additionally the surface morphology and the magnetic properties of the film surface were investigated by AFM and MFM at RWTH Aachen, Germany.

\section{RESULTS AND DISCUSSION}

\section{Depth Distribution Simulation}

SRIM computer code [3] was used to simulate the in depth distributions of the implanted ions in the CVD diamond samples. As shown in Figure 1a, the Fe ions were implanted in the diamond film surface down to 16.7 $\mathrm{nm}$ depth, thus almost on the top most film surface. While Boron was distributed in the film surface deeper up to $55.0 \mathrm{~nm}$, Figure 1b. The Fe ions density is $7 \times 10^{5}$ atom $\mathrm{cm}^{-2}$, while boron ions' is $2.4 \times 10^{5}$ atom $\mathrm{cm}^{-2}$.

The Iron (Fe) ions were implanted into diamond film until at range 167 Angstom (16.7 nm), almost on the top film surface. While Boron (B) was entered the film more deep until range 580 Angstrom $(58.0 \mathrm{~nm})$ due to the 
Surface Modification of Chemical Vapor Deposition (CVD) Diamond/Silicon Film(111) By Implantation With Fe + B Ions and Their Magnetic Properties (Setyo Purwanto, et. all.)

ions mass of Boron lower than the ion mass of Iron as shown in Figure 1. Density of Iron (Fe) ions are $7 \times 10^{5}$ atom $\mathrm{cm}^{-2}$, while Boron ion's is $2.4 \times 10^{5}$ atom $\mathrm{cm}^{-2}$.
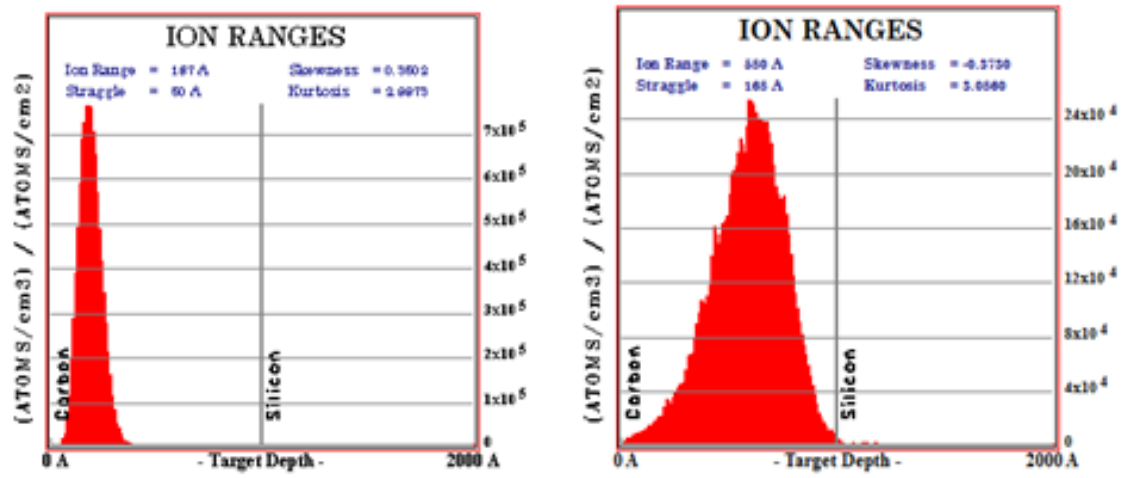

Figure 1. Calculated iron ( $\mathrm{Fe}$ ) ion depth profile (left) and boron $(\mathrm{B})$ ion depth profile (right) implanted into CVD diamond film by SRIM code.

\section{Morphology Surface Film}

The surface morphology of B-E1D1 samples was measured by AFM. The result is shown in Figure 2a. While it's magnetic property was measured by MFM, Figure $2 b$. The surface morphology of sample B-E1D1 shows typical diamond structure. The maximum height of the diamond tip is about $125 \mathrm{~nm}$. MFM view somehow shows magnetic contrast at the same pattern as the AFM result. The distribution of this pattern has maximum height at $107.8 \mathrm{~nm}$. However, the film surface is seems to be smoother in magnetic contrast. This might be related to the existence of Fe ion on the top of surface film as described by SRIM simulation.

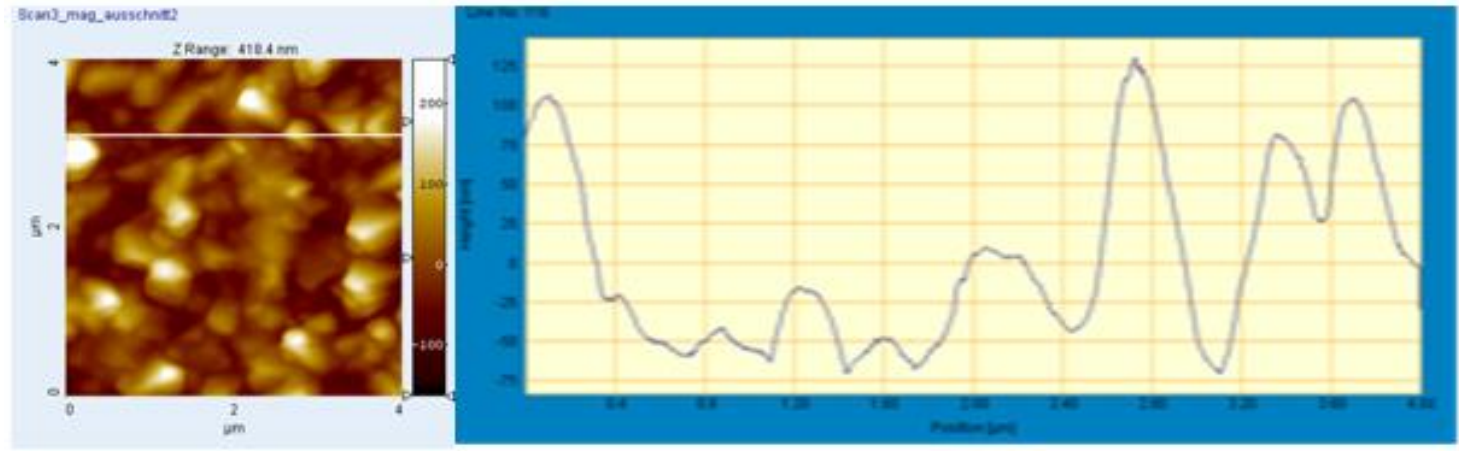

(a)

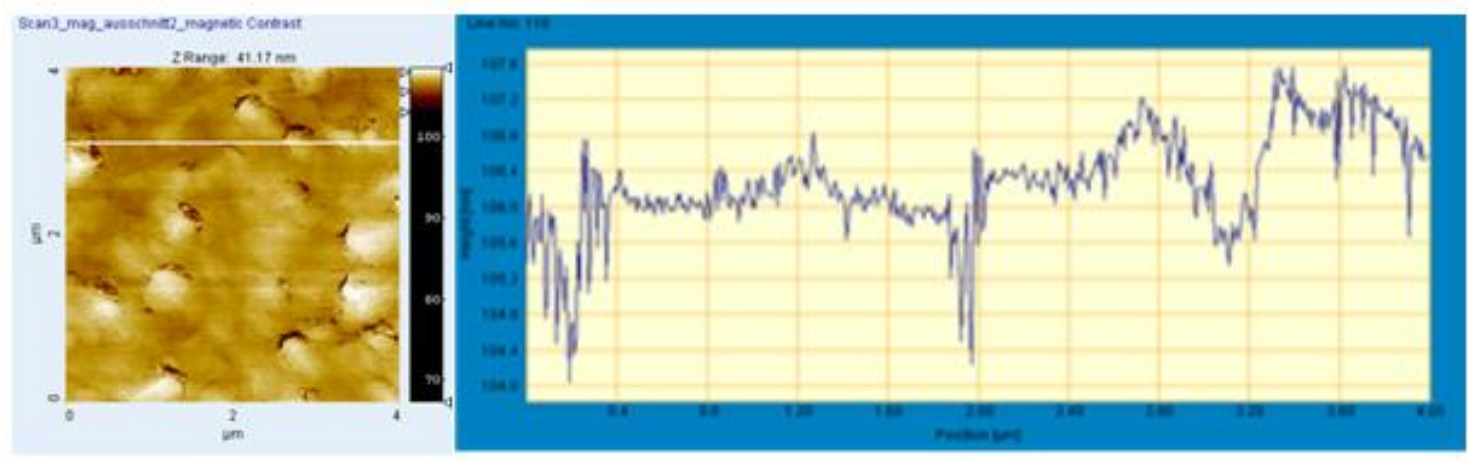

(b)

Figure 2. Surface morphology of samples B-E1D1 seen by AFM (a) and by MFM (b) 
Jurnal Iptek Nuklir Ganendra

Ganendra Journal of Nuclear Science and Technology

Vol. 20, No. 2, Juli $2017: 57-63$

\section{Microstructure Properties (TEM-EELS)}

Figure 3a shows a typical TEM image in scan mode recorded by High Angel Angular Dark Field (HAADF) detector of CVD diamond film cross section after Fe+B ion implantation at dose $1 \times 10^{15}$ ions $\mathrm{cm}^{-2}$ with the total film thickness ca. $1000 \mathrm{~nm}$. One can observe the amorphous layer of $100 \mathrm{~nm}$ thickness on the top of the columnar poly crystal diamond film. The image in Figure $3 \mathrm{~b}$ was acquired using Energy Filter on the EELS boron edge showing the presence of Boron atoms distributed relative homogenously in the amorphous layer.

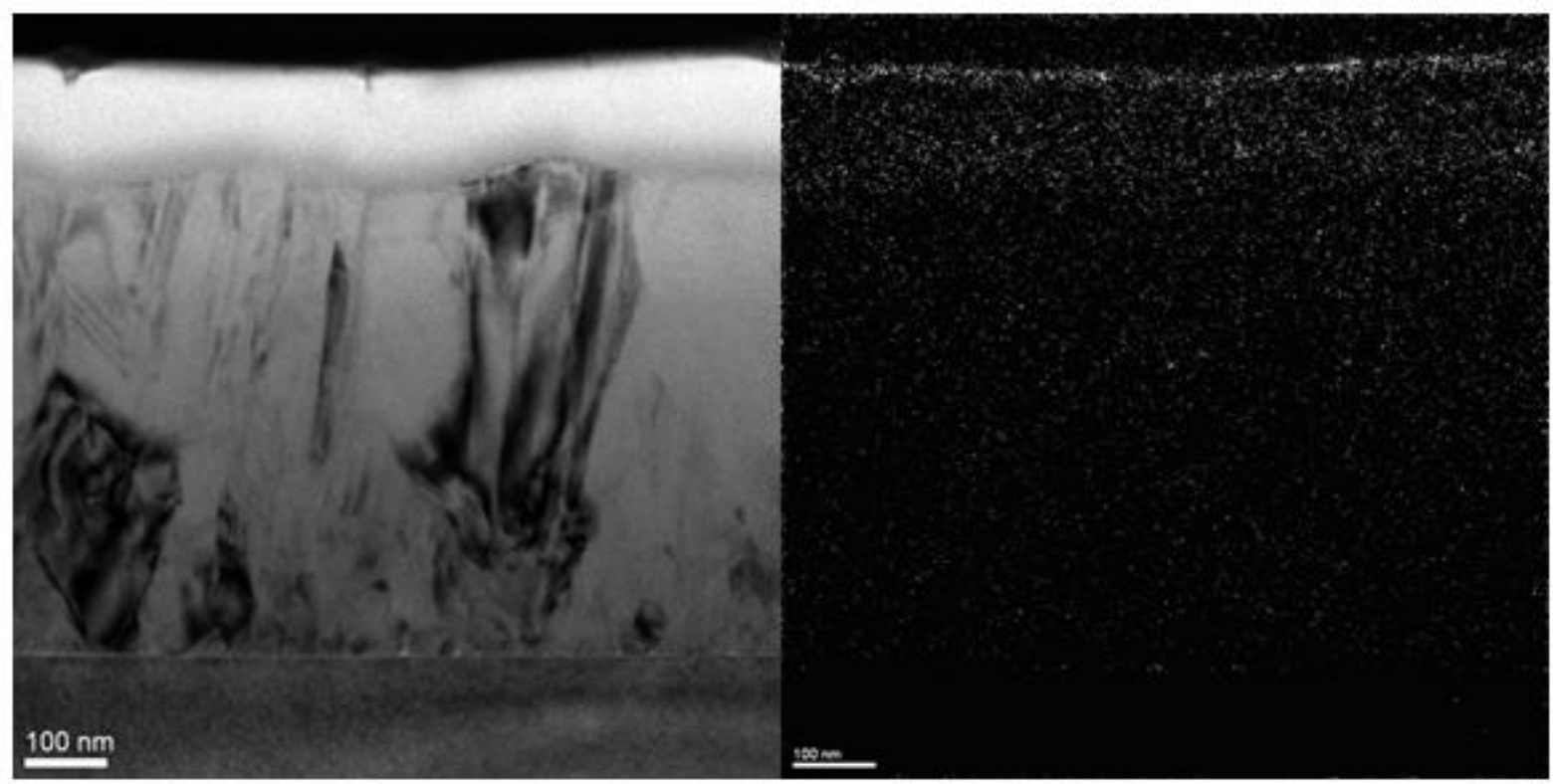

(a)

(b)

Figure 3(a). Left side was a typical of TEM image of CVD diamond film B-E1D1 sample with amorphous diamond around $100 \mathrm{~nm}$ at the top layer

Figure 3(b). Right side were boron atom and amorphous diamond distribution image at the top layer and carbon at the middle of the sample taken by EELS

\section{Raman Spectroscopy}

In order to study the surface condition the Raman spectroscopy measurement at laser energy of $25 \mathrm{~mW}$ is used, because this technique is sensitive to the presence of light element such as Carbon atom. From Raman spectrum in Fig. 4 is obvious, a modification of the diamond surface in the range $1000-1600 \mathrm{~cm}^{-1}$ on both samples. The low dose B-E1D1 sample shows strong Raman peak characteristic for diamond at wave number of $1325 \mathrm{~cm}^{-1}$, while graphite peak is not visible at wave number around $1580 \mathrm{~cm}^{-1}$. At high dose of $1 \times 10^{16}$ ions $\mathrm{cm}^{-2}$ B-E1D2 sample, the diamond characteristic peak became very strong. The graphite peak is not visible. This condition proves that the layer after implantation is free from graphitic bonds as reported earlier in [8]. The wave number of the first and second order of Silicon peaks was found to be 500 and $1000 \mathrm{~cm}^{-1}$, this is in agreement with the result in [9]. Asymmetry peak profile at wave number $1120 \mathrm{~cm}^{-1}$ may be related to the Fano lineshape due to quantum mechanical interference induced by boron dopant. As indicated by the peak at wave number lower than $500 \mathrm{~cm}^{-1}$ the intensity of paired boron atoms increased and have tendency of build up at crystalline boundary by increasing of ion dose [11]. This boron atom pair's accumulation is assumed to contribute to the decreasing of carrier mobility and material conductivity. 


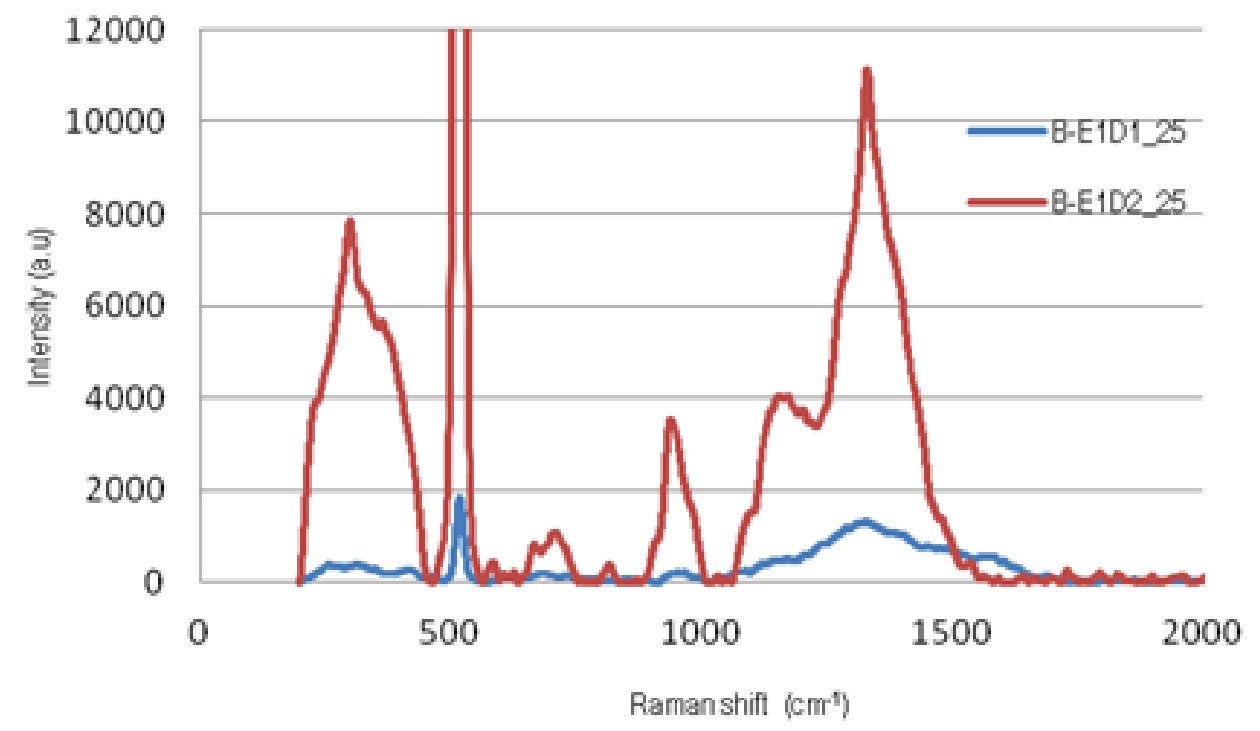

Figure 4. Raman Spectroscopy of $B$ series sample at laser energy $E=25 \mathrm{~mW}$

\section{Magnetic Properties}

The Figure 5 shows the characteristic magnetization curve of the sample B-E1D1 after implantation at 20 $\mathrm{keV}$ and dose $1 \times 10^{15}$ ion $\mathrm{cm}^{-2}$. This curve was measured by VSM with magnetic field up to 1 Tesla $(10 \mathrm{kOe})$ at room temperature. The curve shows a weak ferromagnetic in both parallel and perpendicular to the applied external field direction. The saturated magnetization value $\mathrm{Ms}$ is $0.01 \mathrm{emu} / \mathrm{gram}$ at applied magnetic field 1 Tesla. This is higher than those presented by Hohne et al. for B3 (c) sample which was irradiated by Boron ion at dose $2.31 \times 10^{16}$ ions $\mathrm{cm}^{-2}$ with Ms=0. $6 \times 10^{-6} \mathrm{emu} / 6.5 \mathrm{mg}$ [5]. It is confirmed, on the B-E1D1 sample the Fe and B ions were incorporated in the film and is believed to improve a ferromagnetic character into the CVD diamond sample, without any indication for an interaction between carbon and iron.

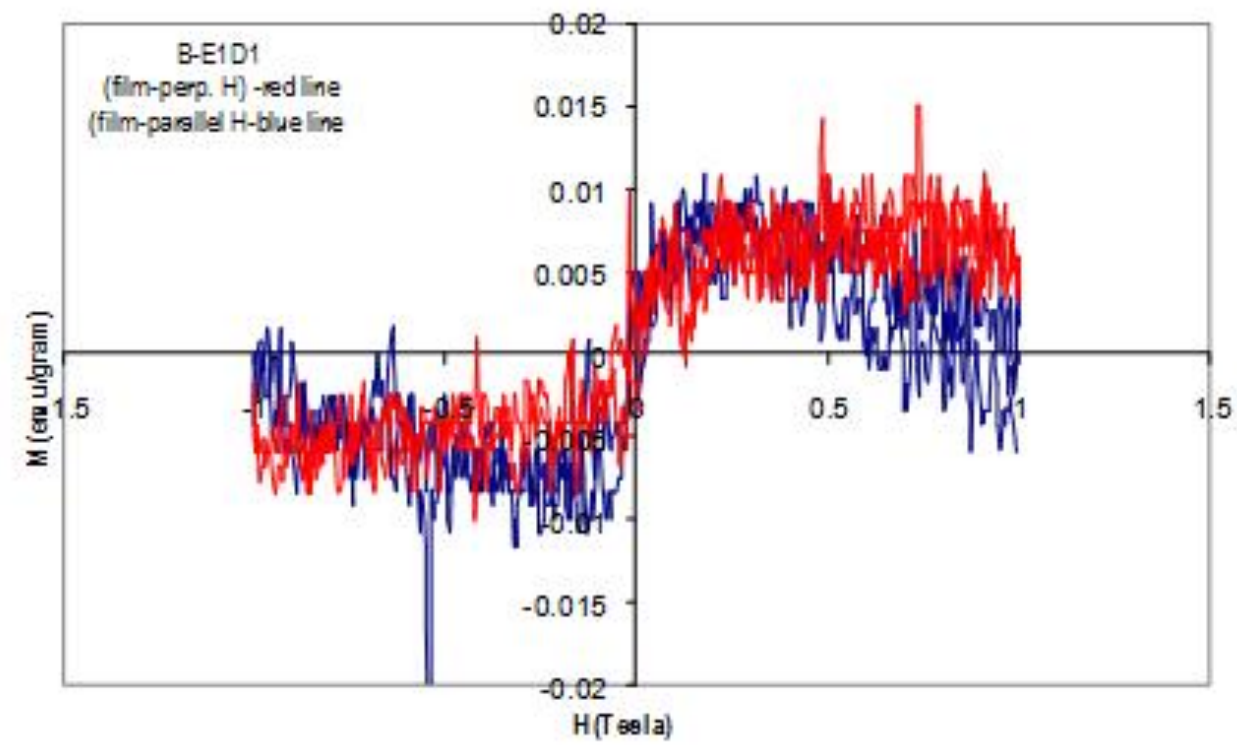

Figure 5. A typical of magnetization curve of CVD diamond film B-E1D1 sample. 
Jurnal Iptek Nuklir Ganendra

Ganendra Journal of Nuclear Science and Technology

Vol. 20, No. 2, Juli 2017 : 57-63

\section{Magnetoresistance Properties}

The measurement of Magnetoresistance properties were performed by Four Point Probe (FPP) method at room temperature with the external magnetic field up to $8 \mathrm{kOe}$. The effect of $\mathrm{Fe}+\mathrm{B}$ implantation on the magnetoresistance is shown in Figure 6. The Magnetoresistance ratio of the samples was clearly depend on

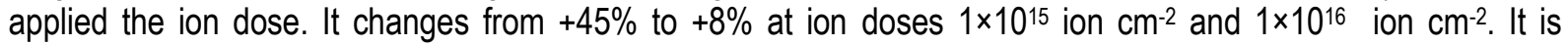
suggested that higher dose caused more damage on the CVD diamond film. In both samples resistance change rate was proportional to $\mu^{2} \mathrm{~B}^{2}$ at low field and coincidence with other result as reported in [5]. It indicates also that the defects produced by higher doses ion implantation give contributions to the conductivity in diamond film as reported in [10]. Such kind of phenomenon could explain by a localization of the wave function on B-atoms as reported by Willems et al. [12].

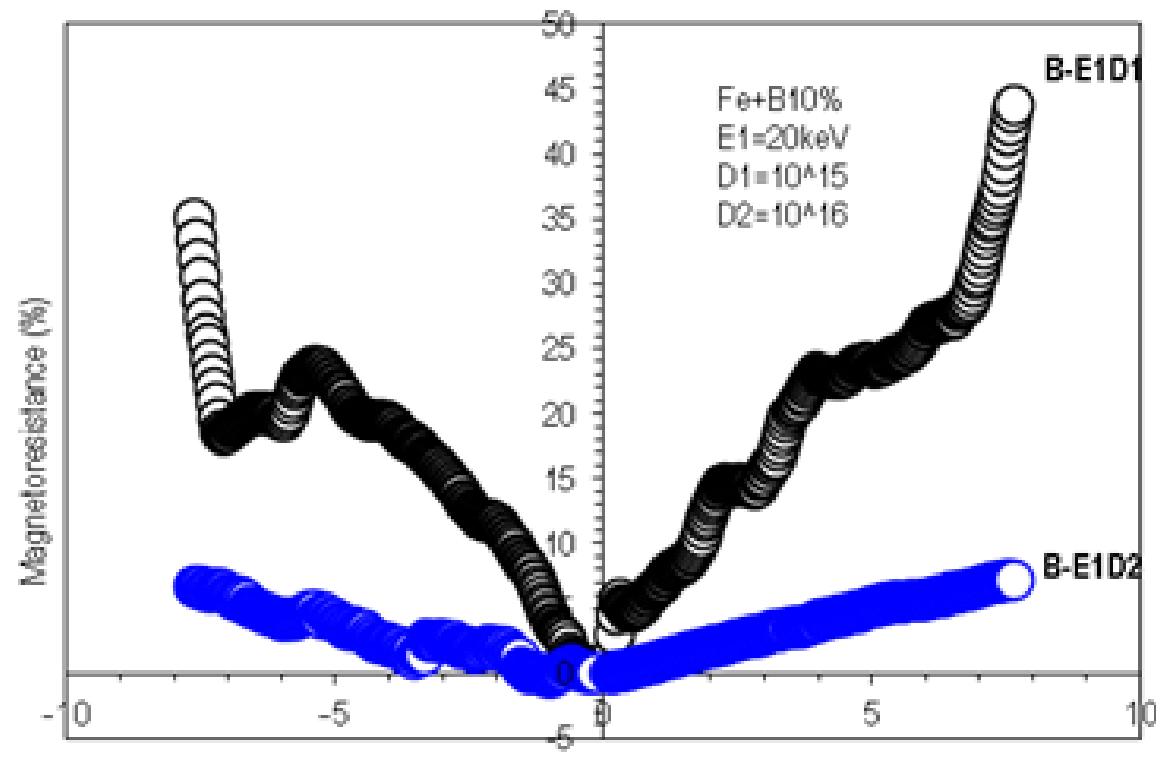

Magnetic Field (kOe)

Figure 6. Magnetoresistance curve of CVD diamond film post implanted ion $\mathrm{Fe}+\mathrm{B}$

\section{CONCLUSION}

In summary, surface modifications of CVD manufactured Diamond Films on Si(111) substrate have been successfully performed by $\mathrm{Fe}+\mathrm{B}$ ions implantation followed by Argon gas pouring as ion impact growth at accelerated energy 20 and $70 \mathrm{keV}$ and dose $1 \times 10^{15}$ and $1 \times 10^{16}$ ion $\mathrm{cm}^{-2}$. TEM equipped with the EELS revealed growth of amorphous carbon layer on top of the Diamond film with thickness of about $100 \mathrm{~nm}$ on the implanted sample- Boron atoms have been found incorporated inside the carbon amorphous layer with the relatively homogeneous distribution. This result is in close agreement to the Raman Spectroscopy result which obviously indicates changes on the Raman spectrum due to implantation. The ferromagnetic character of the sample after $\mathrm{Fe}+\mathrm{B}$ implantion has also been studied. At applied magnetic field of 0.8 Tesla and ion energy $20 \mathrm{keV}$, the magnetoresistance ratio decreased from $+45 \%$ on low dose to $+8 \%$ on high dose.

\section{ACKNOWLEDGMENT}

Authors gratefully thank to Kementrian Riset dan Teknologi for financial support for the FIB and TEM investigation in Germany, for Dr. Anke Aretz for MFM measurement. Special thank to Mr. Sunarto PSTA-BATAN for helping during implantation process. 


\section{REFERENCES}

[1] S. Talapatra, J.Y. Cheng, N. Chakrapani, S. Trasobares, A. Cao, R. Vajtai, M.B. Huang, P.M. Ajayan. "Ion irradiation induced structural modifications in diamond particles", Nanotechnology,vol.17, pp.305-309, 2006.

[2] Balasubramanian, G., Chan, I. Y., Kolesov, R., Al-Hmoud, M.,Tisler, J., Shin, C., Kim, C., Wojcik, A., Hemmer, P. R., Krueger,A.,et al. "Nanoscale Imaging Magnetometry with Diamond Spins under Ambient Conditions", Nature, vol.455, pp. 648-651, 2008.

[3] J.F. Ziegler : http://SRIM.org

[4] C. Tavares, F. Omnes, J. Pernot, E. Bustarret ." Electronic properties of boron-doped \{111\}-oriented homoepitaxial diamond layer", Diamond and Related Materials, vol.15, pp. 582-585, 2006.

[5] R. Höhne, P. Esquinazi, V. Heera, H. Weishart . "Magnetic properties of ion-implanted diamond", Diamond \& Related Materials, vol. 16, pp. 1589-1596, 2007.

[6] J.Y. Fei, D. Yang, X. Wang, Q.B. Meng, Xuejin Wang, Y.Y. Xiong, Y.X. Nie, Ke-an Feng." Magnetoresistance of Boron Doped CVD polycrystalline films", Diamond and Related Materials, vol.11, no.1, pp. 49-52, 2002.

[7] J. Mayer, H.-J. Penkalla, A. Dimyati, M. Dani, P. Untoro, D. Naumenko, and W.J. Quadakkers." Time dependence of Mg-incorporation in alumina scales on FeCrAl alloys studied by FIB - prepared TEM cross sections", Mater. at High Temp, vol.20, pp. 167-173, 2003.

[8] P.W. May, J.A. Smith, K.N. Rosser ." 785 nm Raman spectroscopy of CVD diamond film", Diamond \& Related Materials, vol.17, pp. 199-203, 2008.

[9] P.W. Way, W.J. Ludlow, M. Hannaway, P.J. Heard, J.A. Smith, K.N. Rosser," Raman and conductivity studies Boron-doped microcrystalline diamond, facetted nanocrystalline diamond and cauliflower diamond films", Diamond \& Related Materials, vol.17, pp. 105-117, 2008.

[10] X.J. Hu, J.S. Ye, H.J. Liu, H. Hu, X.H. Chen,"The influence of oxygen ion implantation on the structural and electrical properties of B-doped diamond films", Diamond and Related Materials, vol.20, pp. 246-249, 2011.

[11] Kevin E. Bennet, Kendall H. Lee, James N. Kruchowski, Su-Youne Chang , Michael P. Marsh,

[12] Alexander A. Van Orsow, Aurelio Paez and Felicia S. Manciu." Development of Conductive Boron-Doped Diamond Electrode: A microscopic, Spectroscopic, and Voltammetric Study", Materials, vol.6, pp. 57265741, 2013.

[13] B.L. Willems, G. Zhang, J. Vanacken, V.V. Moshchalkov, S.D. Janssens, O.A. Williams, K. Haenen, P. , Wagner,"Negative magnetoresistance in boron doped nanocrystalline diamond films", J. of Appl. Phys. vol.106, p. 033711, 2009. 